\title{
Micromorphological variations of trichomes in the genus Ocimum L.
}

\author{
Sanoj $E^{1}$, Deepa $\mathrm{P}^{*}$ \\ ${ }^{1}$ Department of Botany, The Zamorin's Guruvayurappan College, Kozhikode 673 014, Kerala, India \\ ${ }^{2}$ Department of Botany, Farook College, Kozhikode 673 632, Kerala, India \\ *Email: deepapsaj@gmail.com
}

\section{ARTICLE HISTORY}

Received: 21 October 2020

Accepted: 24 March 2021

Available online: 01 July 2021

KEYWORDS

Ocimum

Peltate trichome

Taxonomic key

Secretory hairs

Defensive mechanism
ABSTRACT

Ocimum L. is an attractive fragrant ornamental plant with medicinal aromatic compounds. The study using digital microscopy revealed the distinct epidermal trichome morphology in five species of Ocimum including O. americanum L., O. basilicum L., O. gratissimum L., O. kilimandscharicum Gurke and $O$. tenuiflorum L. A distinguished variation in size, shape, type and abundance of trichomes on leaves and stem of all species are described and photographed. Both glandular and non-glandular trichomes scrutinized in all the species in which glandular type comprised capitate and peltate trichomes. On the stem, the longest glandular capitate trichome (GCT) and non-glandular trichome (NGT) were observed in 0 . tenuiflorum while $O$. basilicum possessed longest glandular peltate trichome (GPT). In case of foliar trichomes, the longest GCT observed on leaves of O. americanum; and O. basilicum showed the longest GPT and NGT. In the species, the septate or aseptate NGT possessed uni, bi or multicellular base with acute or broad apex. A distinguished variation in the number of cells in stalk and head of GT was observed in the study. Presence of silica bodies in peltate trichome of $O$. kilimandscharicum was noticed as the characteristic feature. Among the five species, the trichomes were abundant in $\mathrm{O}$. kilimandscharicum; while O. basilicum showed sparse distribution. Trichomes with disrupted cells were also noted in $O$. americanum. Due to the presence of specific trichome characteristics, the efficient taxonomic key is prepared to identify the taxa at species level.

\section{Introduction}

Lamiaceae includes around 250 genera and 7000 species that particularly well represented in tropical and temperate areas (1). While some species are characteristic of semi-arid conditions and many others are adapted to wet habitats in seasonally flooded areas or along river banks in forest. The family divided into two main groups based on number of aperture and nuclei in shed pollen (2). The first and second group comprises the subfamilies Lamioideae and Nepetoideae respectively (3). Nepetoideae has often strongly aromatic species with volatile terpenoids, rosmarinic acid and hexacolpate pollens.

Most of the members of Lamiaceae display both glandular and non-glandular trichomes on different plant parts $(4,5)$. The xeromorphic species have welldeveloped trichomes to ensure the preservation of entire plant from xeromorphic changes (6). Three main types of trichomes like peltate, capitate and nonglandular were observed on the stem, inflorescence axis, leaf and calyx surfaces of Salvia chrysophylla Stapf, Thymus quinquecostatus Celak and Lamium truncatum Boiss that possess the secretions contained essential oil, polyphenols, flavonoids and acid polysaccharides (7-11). In many of the species, the essential oils produced glandular trichomes spread over the aerial vegetative and reproductive parts. Moreover, the non-glandular trichomes protect the plants from different abiotic stresses like high temperature and light intensity, UV rays, low humidity etc. Recent studies indicate the common occurrence of glandular trichomes in members of Lamiaceae, Bignoniaceae, Asteraceae and Brassicaceae which release the proteins for defensive mechanism or valuable secondary metabolites that can be utilized for the production of pharmaceuticals $(4,12-16)$.

The genus Ocimum L. belongs to the sub-family Napetoideae of the tribe Ocimeae that included about 65 species of herbs and shrubs (17). Plants of this genus are collectively called 'basil' which play as the source of essential oils and aromatic compounds (18). The valuable medicinal plant, Ocimum sp., thrives well in a variety of soils and climatic conditions. Soils suitable for cultivation are rich loam to poor laterite, and saline and alkaline to moderately acidic. Welldrained soil helps to encourage improved vegetative growth. It flourishes well under fairly to high rainfall 
and humid conditions, and long days and high temperature have been found to be favourable for plant growth and higher oil production (19). It is native in Asia, Africa, South and Central America, but widely distributed around the world (17). The aromatic and medicinal plants used fresh or dried as a drug in traditional medicine and as a flavoring agent for foods, confectionary products and beverages (20). The plants are used to prepare many herbal medicines due to the antimicrobial properties (21). Plant trichome induction is depending to the level of phytohormones and other primary metabolites produced in the plants during different stages of life cycle that including gibberellins (GA), salicylic acid (SA), jasmonic acid (JA) and cytokinin (CTK). The differential plant metabolism in turn causes variation in trichome morphology and distribution (22). While the information on trichome morphology in different species of Ocimum is scanty; so the present study focused on scrutinization of trichome diversity among six species of Ocimum in Kerala.

\section{Materials and Methods}

\section{Plant collection}

For the study, five species of Ocimum including $O$. americanum, $O$. basilicum, $O$. gratissimum, $O$. variations of trichomes. The size, position, type, abundance and structure of base, stalk and apical cell of trichomes were studied using Motic B1-Series Digital Microscope. The morphological trichome variations among the species were photographed by the attached camera of microscope. The size of trichomes measured using Motic Image Plus 2.0 software.

\section{Results and Discussion}

Recent plant taxonomy considers trichome structure as the key character for identification of taxon. The present investigation focused on plant morphology and trichome analysis in five major species of Ocimum in Kerala, provides a better taxonomic key to identify the species (Table 1). The study revealed the presence of both glandular and non-glandular trichomes in all five species; beyond, the glandular trichomes included capitate and peltate types. The trichomes of the genus categorized into six major types based on their micromorphology (Table 2). As part of the plant systematics, Abdulrahman and Oladele studied the glandular and non-glandular trichomes in six species of the genus Ocimum (23). Similarly, Observations are made on the glandular trichomes on the vegetative organs of Ocimum selloi Benth (24). In Ocimum, the peltate and subsessile capitate glandular trichomes were distinct on the

Table 1. Morphological characters of Ocimum L. spp.

\begin{tabular}{|c|c|}
\hline Species & Morphological characters \\
\hline O. tenuiflorum L. & $\begin{array}{l}\text { Subshrub. Leaves elliptic-oblanceolate, obtuse at both ends, margin coarsely serrate, puberulous; } \\
\text { petiole covered with reddish-purple hairs. Raceme simple, occasionally branched at base. Bracts } \\
\text { suborbicular. Calyx purplish, campanulate; lobes 5, upper lip ovate, acute, lower lip hispid. Corolla } \\
\text { reddish-pink, tubular-campanulate; tube with sessile oil glands; lobes of upper lip oblong-orbicular; } \\
\text { lower lip ovate-oblong. Stamens 4. Nutlet sub-trigonous, dark brown. }\end{array}$ \\
\hline O. americanum $\mathrm{L}$. & $\begin{array}{l}\text { Woody herb. Leaves simple, opposite, elliptic, acute to acuminate, base truncate or obtuse, } \\
\text { subentire, sparsely hairy or glabrous. Raceme densely pubescent; flowers 5-7 in each whorl. Calyx } \\
\text { upper lip orbicular, densely hairy. Corolla white, glabrous. Staminal filaments glabrous. Nutlet sub- } \\
\text { trigonous, dark brown. }\end{array}$ \\
\hline O. basilicum L. & $\begin{array}{l}\text { Erect annual herb; stem obtusely 4-angular. Leaves ovate-elliptic, base cuneate, margin entire to } \\
\text { distantly crenulate, apex acute, puberulous above, pubescent with sessile oil galnds beneath. Calyx } \\
\text { tube c. } 3 \mathrm{~mm} \text { long, sparsely strigose; upper lip broadly ovate; lower lip hairy within. Corolla cream; } \\
\text { tube inflated below; lobes } 5 \text {. Stamens } 4 \text {. Nutlet ellipsoid, black, mucilaginous. }\end{array}$ \\
\hline O. gratissimum L. & $\begin{array}{l}\text { Shrub. Leaves simple, opposite, elliptic to obovate, acuminate at apex, base attenuate serrate. } \\
\text { Racemes terminal, panicles; bracts oblanceolate; flowers 4-6 at each node. Calyx glabrous; upper lip } \\
\text { ovate, obtuse, lobes of lower lip acuminate, glandular. Corolla white, lobes obtuse. Staminal } \\
\text { filaments glabrous or villous at base; anthers sagittate at base. Nutlet brown. }\end{array}$ \\
\hline O. kilimandscharicum Guerke. & $\begin{array}{l}\text { Perennial herb. Leaf ovate-oblong, pubescent with white hairs. Inflorescence greenish-greyish. } \\
\text { Flowers white. Calyx greenish-greyish, densely hairy. Seed black, mucilaginous. }\end{array}$ \\
\hline
\end{tabular}

kilimandscharicum and $O$. tenuiflorum were collected from the 'Herbal Garden' of Arya Vaidya Sala, Kottakkal, Malappuram, Kerala and identified by Dr. A. K. Predeep, Department of Botany, University of Calicut.

\section{Trichome study}

Both preserved and fresh materials were used for the study. The plants preserved in 10\% formaldehyde and prepared herbarium specimens by conventional dry method. For micromorphological study, the thin hand cross-sections made from the live or preserved materials using commercial razor blade. The sections stained with safranin and mounted in glycerine. About 3-5 specimen slides of leaf and stem were prepared in order to study the morphological stem and leaves of the species. Obviously, the presence of glandular trichomes can be considered as the key character of the present genus.

\section{Trichome diversity on stem}

The distinct morphological structural variations in trichomes are visible on leaves and stem of all species. Both environmental and genetic factors determine the unique features of trichomes in each taxon. Sometimes, the different species grown in same environmental conditions showed dissimilar trichome morphology due to genetic reason (25). In $O$. americanum, $O$. kilimandscharicum and $O$. tenuiflorum, stem possesses three types of trichomes including capitate, peltate and non-glandular; while capitate and peltate types were observed in $O$. 
Table 2. Different types of trichomes observed in selected species of Ocimum L.

\begin{tabular}{|c|c|}
\hline Type & Micromorphology \\
\hline \multirow{4}{*}{1} & Non glandular, base unicellular \\
\hline & A. Short, aseptate with acute apex \\
\hline & B. Short, septate with acute apex \\
\hline & C. Long, septate with acute apex \\
\hline \multirow{3}{*}{2} & Non glandular, base bicellular \\
\hline & A. Septate with acute apex \\
\hline & B. Septate with broad apex \\
\hline \multirow{3}{*}{3} & Non glandular, base multicellular \\
\hline & A. Septate with acute apex \\
\hline & B. Septate broad apex \\
\hline \multirow{3}{*}{4} & Glandular, stalk unicellular \\
\hline & A. Unicellular stalk with unicellular head \\
\hline & B. Unicellular stalk with multicellular head \\
\hline \multirow{3}{*}{5} & Glandular, stalk bicellular \\
\hline & A. Bicellular stalk with unicellular head \\
\hline & B. Bicellular stalk with multicellular head \\
\hline 6 & Glandular, stalk multicellular. \\
\hline
\end{tabular}

basilicum and $O$. gratissimum. Among the 5 species studied, $O$. tenuiflorum showed the longest capitate trichome; whereas $O$. basilicum displayed the shortest one on stem. In case of peltate type, O. basilicum had longest as well as shortest trichomes. At the same time, $O$. tenuiflorum showed the longest nonglandular trichomes and $O$. americanum exhibited the shortest (Table 3). The considerable variation in density of trichomes also observed between species. The higher trichome density scrutinized on stem of $O$. gratissimum, $O$. kilimandscharicum and $O$. tenuiflorum and these three species had better abundance of different types of trichomes that indicate the formation of unique trichome types in each species (Table 4).

The effect of environmental stimuli such as temperature, altitude and season, drought stress, light intensity and toxicity of minerals on glandular trichome formation has been found in different medicinal plants (15). This multifactorial character is clear from the investigation describing the specific in the study. In Begonia dregei, the deeply incised leaves had larger numbers of longer trichomes at the sinuses; beyond, higher numbers of trichomes observed on the abaxial surface (26).

Among the Ocimum spp., O. basilicum possessed glandular trichomes only. In this, the capitate type was with unicellular stalk and head, whereas head of peltate type had unicellular or multicellular nature (Fig. 2. M-O). The species is considered as the main site of production of essential oils due to the presence of glandular trichomes (27). The major phytoconstituents of essential oil in Ocimum species are phenylpropanoids and terpenoids. Production of these secondary metabolites is correlated with specific genes. This trichome related genes identified from the Ocimum species; however, these genes are highly expressed in O. basilicum (28).

In $O$. gratissimum, the presence of capitate, peltate and non-glandular types was observed on the stem. Peltate type had basal epidermal cell, unicellular stalk and multicellular head. In contrast, capitate type developed from single epidermal cell. Oftenly, uniseriate 4-celled non-glandular trichomes with multicellular base intermingled with glandular types (Fig. 1. A-C). Similarly, microscopic examination on stem of $O$. kilimandscharicum described the presence of capitate, peltate and non-glandular trichomes in varying density. Capitate trichomes showed unicellular or multicellular base and unicellular head, while the multicellular head observed in peltate type. The long uniseriate nonglandular trichomes had unicellular or multicellular base and hooked or acute apex with flagelliform shape (Fig. 1. H-K). In O. tenuiflorum, capitate type possessed unicellular or multicellular stalk and secretary unicellular or multicellular head. In addition to this, peltate type exhibited short and unicellular stalk with broad round multicellular secretary head composed of 4-12 cells. Whilst, the

Table 3. Types and length of trichomes on leaves and stem in different species of Ocimum L.

\begin{tabular}{|c|c|c|c|c|c|c|}
\hline \multirow{2}{*}{ Species } & \multicolumn{3}{|c|}{ Foliar trichomes $(\mu \mathrm{m})$} & \multicolumn{3}{|c|}{ Stem trichomes $(\mu \mathrm{m})$} \\
\hline & GCT & GPT & NGT & GCT & GPT & NGT \\
\hline O. americanum & $26-79$ & $34-75$ & $50-140$ & $40-60$ & c. 32.7 & 81-389 \\
\hline O. basilicum & - & $41-83$ & c. 390 & $30-32$ & $25-80$ & - \\
\hline O.gratissimum & $31-44$ & - & $68-322$ & $31-44$ & $33-42$ & - \\
\hline O. kilimandscharicum & c. 39 & $40-80$ & $26-256$ & $40-67$ & $48-56$ & $232-526$ \\
\hline O. tenuiflorum & $31-48$ & - & $34-145$ & $31-112$ & $43-65$ & $157-846.6$ \\
\hline
\end{tabular}

(GCT-Glandular Capitate Trichome, GPT-Glandular Peltate Trichome, NGT-Non-Glandular Trichome)

characteristic features of base, stalk and head in trichomes of Ocimum species. In $O$. americanum, capitate trichomes were with multicellular or unicellular base and single celled head; while peltate trichomes possessed unicellular base, stalk and head. A distinguished structural variation observed in nonglandular trichomes; these were uniseriate and 2-5 celled with unicellular base. Moreover, the trichomes carrying disrupted cells were also observed on the surface of stem (Fig. 2. G-J). A significant correlation between the shapes of leaves and the presence, number and size of trichomes among taxa was clear uniseriate unbranched non-glandular type showed broad or curved apex and unicellular or multicellular base (Fig. 1. P-R).

In most plants more than one type of trichomes was observed; while, the presence of non-glandular trichomes was the most dominant feature of Vitex negundo L., Isodon rugosus (Wall. ex Benth.) Codd, Colebrookea oppositifolia Sm. and Marrubium vulgare L. (29). In members of some families, the glandular trichomes were only detected that may or may not be bearing secondary metabolites. The stalked glandular trichomes of Pelargonium sp., Solanum sp., 
Table 4. Occurrence of different types of trichomes in Ocimum spp.

\begin{tabular}{|c|c|c|c|c|c|c|c|c|c|c|}
\hline \multirow{2}{*}{ Trichome types } & \multicolumn{2}{|c|}{ o. americanum } & \multicolumn{2}{|c|}{ O. basilicum } & \multicolumn{2}{|c|}{ O. gratissimum } & \multicolumn{2}{|c|}{ O. kilimandscharicum } & \multicolumn{2}{|c|}{ O. tenuiflorum } \\
\hline & Leaf & Stem & Leaf & Stem & Leaf & Stem & Leaf & Stem & Leaf & Stem \\
\hline Type 1-A & $+\mathrm{b}$ & - & - & $+\mathrm{b}$ & $+\mathrm{b}$ & - & - & - & - & - \\
\hline Type 1-B & $+a$ & - & $+\mathrm{b}$ & - & - & - & - & $+a$ & - & - \\
\hline Type 1-C & - & $+\mathrm{b}$ & - & - & $+\mathrm{a}$ & - & $+a$ & $+\mathrm{b}$ & $+\mathrm{a}$ & $+\mathrm{a}$ \\
\hline Type 2-A & $+\mathrm{b}$ & - & - & - & - & - & - & - & $+\mathrm{b}$ & - \\
\hline Type 2-B & $+\mathrm{b}$ & - & - & - & - & - & $+\mathrm{b}$ & - & - & - \\
\hline Type 3-A & $+\mathrm{a}$ & - & - & - & - & - & - & - & $+\mathrm{a}$ & $+\mathrm{a}$ \\
\hline Type 3-B & - & $+\mathrm{b}$ & - & - & - & $+\mathrm{b}$ & - & - & $+a$ & $+\mathrm{b}$ \\
\hline Type 4-A & $+\mathrm{b}$ & - & - & - & $+\mathrm{b}$ & $+\mathrm{a}$ & $+\mathrm{b}$ & $+\mathrm{a}$ & $+\mathrm{b}$ & $+\mathrm{a}$ \\
\hline Type 4-B & - & - & - & - & - & $+\mathrm{b}$ & - & $+\mathrm{b}$ & - & - \\
\hline Type 5-A & - & - & - & - & - & - & $+\mathrm{b}$ & $+\mathrm{b}$ & - & $+\mathrm{b}$ \\
\hline Type 5-B & - & - & - & - & - & - & - & - & $+\mathrm{b}$ & $+\mathrm{b}$ \\
\hline Type 6 & - & - & - & - & - & - & - & - & $+\mathrm{b}$ & - \\
\hline
\end{tabular}

Lycopersicon sp., Cucurbita sp., and Abutilon sp. consisted $\omega 5$-fatty acids, precursor of anacardic acid which can be separated from tissues by isolating the glandular trichomes. The anacardic acid is using in chemical industry to prepare resins, coatings, frictional materials etc. (30).

\section{Foliar trichome morphology}

The leaves display trichomes on both upper and lower epidermis having specific functions like protection from environmental stresses. Each species shows distinct diversities in trichome distribution in turn helps to identify the taxa at taxonomic level. However, the young leaves are densely covered with trichomes and the density of trichomes decreases progressively with leaf maturity. Hence, the trichomes are established early in leaf differentiation and their density decreases with leaf development and age (31). The occurrence of capitate and peltate glandular trichomes in leaves of Ocimum selloi has been documented $(32,33)$. It is characteristic feature of the genus Ocimum that produce oil drops by the activity of plastids present in the head cells of trichomes (34). Present study confirms the occurrence of glandular and non-glandular trichomes on the abaxial and adaxial sides of Ocimum leaves. Leaves showed the occurrence of numerous peltate trichomes compared to the stem. Among the species, O. basilicum, O. americanum and $O$. kilimandscharicum had glandular peltate trichomes of which $O$. basilicum displayed the longest and $O$. americanum possessed the shortest. Interestingly, all species except $O$. basilicum exhibited capitate trichomes in which $O$. americanum showed the longest one. Always, the length of non-glandular trichome is higher than glandular trichomes that vary from 26-390 $\mu \mathrm{m}$. From the study, it is clear that $O$. basilicum had longest non-glandular trichomes whereas $O$. kilimandscharicum showed the shortest (Table 3).

There are reports on the occurrence of 8 different types of non-glandular and glandular trichomes on the leaf surfaces in eight species of Kalanchoe Adans. (Crassulaceae DC.), which is considered as an important adaptation to the conditions of the natural environment (35).
Likewise, a wide diversity in trichome structure and occurrence is evident on leaves of Ocimum species. In $O$. americanum, capitate trichomes were with unicellular base and head; while unicellular or multicellular head observed in peltate type. The uniseriate non-glandular trichomes had acute apex and unicellular or multicellular base (Fig. 2. A-F). But, $O$. basilicum showed peltate and non-glandular foliar trichomes in which peltate type was with multi-cellular head. The non-glandular trichomes had uniseriate and segmented nature with acute apex (Fig. 2. K-L).

Peltate trichomes arise as epidermal protuberances that possess basal cell, stalk and apical head cell. Commonly, peltate glandular trichomes are localized on the adaxial and abaxial leaf surfaces in Lamiaceae. Eventhough, variation in size is highly noticeable among the taxa; they can act as a well-generated excretory system (36). In $O$. gratissimum, capitate and non-glandular trichomes were examined on adaxial side of leaves. Capitate type showed unicellular base, stalk and head; while, the non-glandular trichomes are long, unicellular or multicellular with acute apex (Fig. 2. P-R). Trichomes with homogenous morphology are described in $O$. gratissimum and in other Lamiaceae spp. $(13,37)$. Similar to $O$. americanum, the trichomes in $O$. kilimandscharicum were glandular and non-glandular type in which capitate trichomes had unicellular base and multicellular head. Interestingly, peltate type showed silica deposition in the multicellular head. The nonglandular type was segmented uniseriate broad with hooked or acute apex (Fig. 1. D-G). Silica deposition in plant tissues is one of the important characteristics of the families Poaceae, Asteraceae, Cucurbitaceae etc. (38-40). In Pleioblastus chino (Franch. \& Sav.) Makino, the silica deposition observed in epidermal prickle hairs of leaves (40). Similarly, silica bodies were also detected on both abaxial and adaxial epidermis of Koeleria macrantha leaves, although their sizes, density and distribution patterns were different.

Usually, the light intensity and trichome development is positively correlated in plants. But there was no effect of light treatments on the glandular trichome density and essential oil 


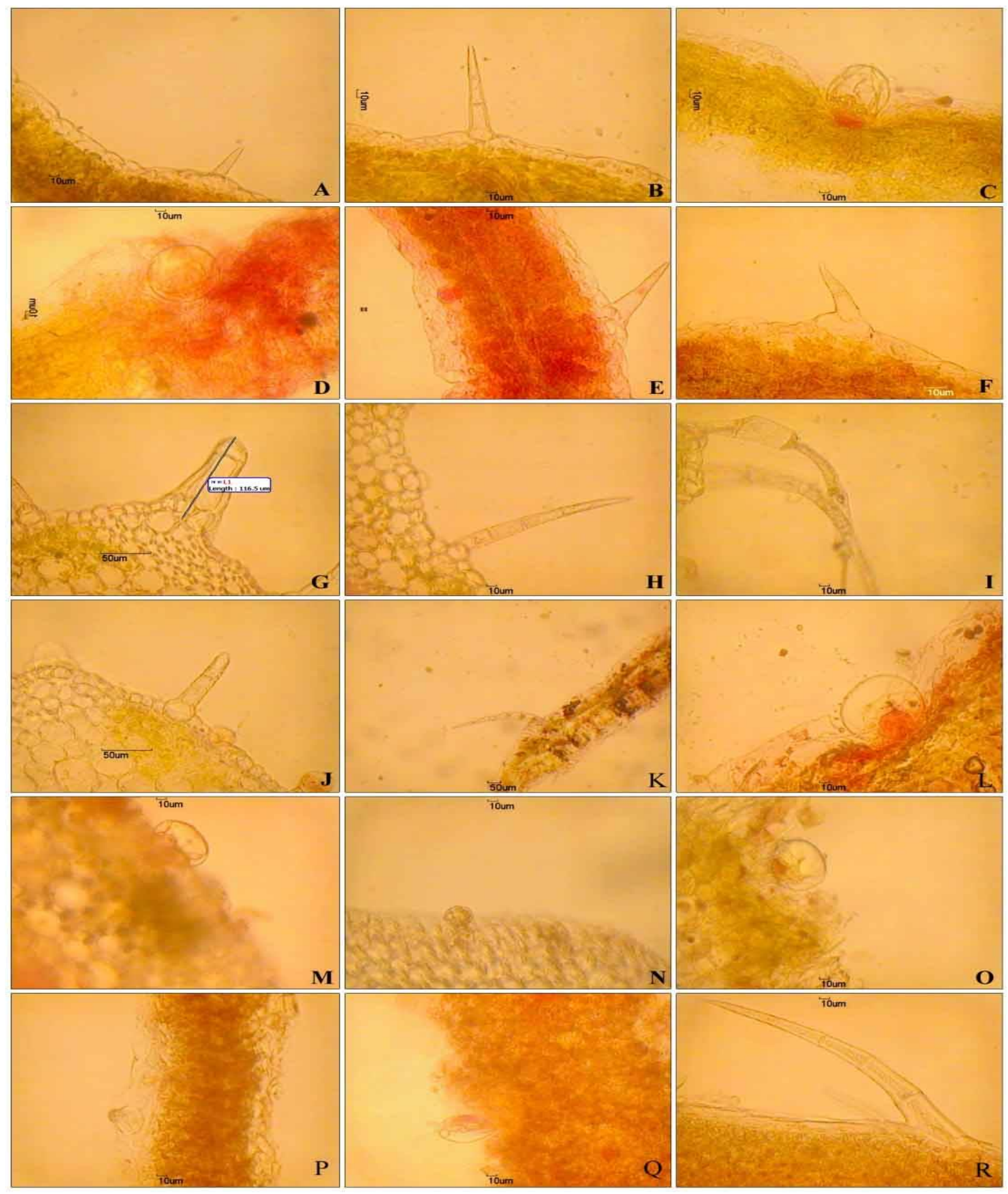

Fig. 2. Trichomes; A-F. O. americanum - Leaf; G-J. O. americanum - Stem; K-L. O. basilicum - Leaf; M-O. O. basilicum - Stem; P-R. O. gratissimum - Leaf.

content (11). O. obovatum had two types of glandular trichomes on the leaves: large peltate and small capitate. In this species, the secretions of peltate and capitate heads are gradually transported from protoplast to the subcuticular space via fracture or pore at the connecting walls of the head cells (27). The rupture of the cuticle on the head cells seems to be a common feature of glandular trichomes in Lamiaceae spp. (41). The essential oil produced on the leaves of $O$. selloi has repellent and antimicrobial activities to protect the plant from herbivores and pathogens (42). Presence of capitate and non-glandular trichomes in $O$. tenuiflorum makes the species unique from others. Here, capitate type possessed single celled stalk with secretary uni or multicellular head. The non-glandular trichomes were long, segmented, uniseriate with multicellular or unicellular base and broad or acute apex (Fig. 1. L-O). The pronounced expression of animal metallothioneins 


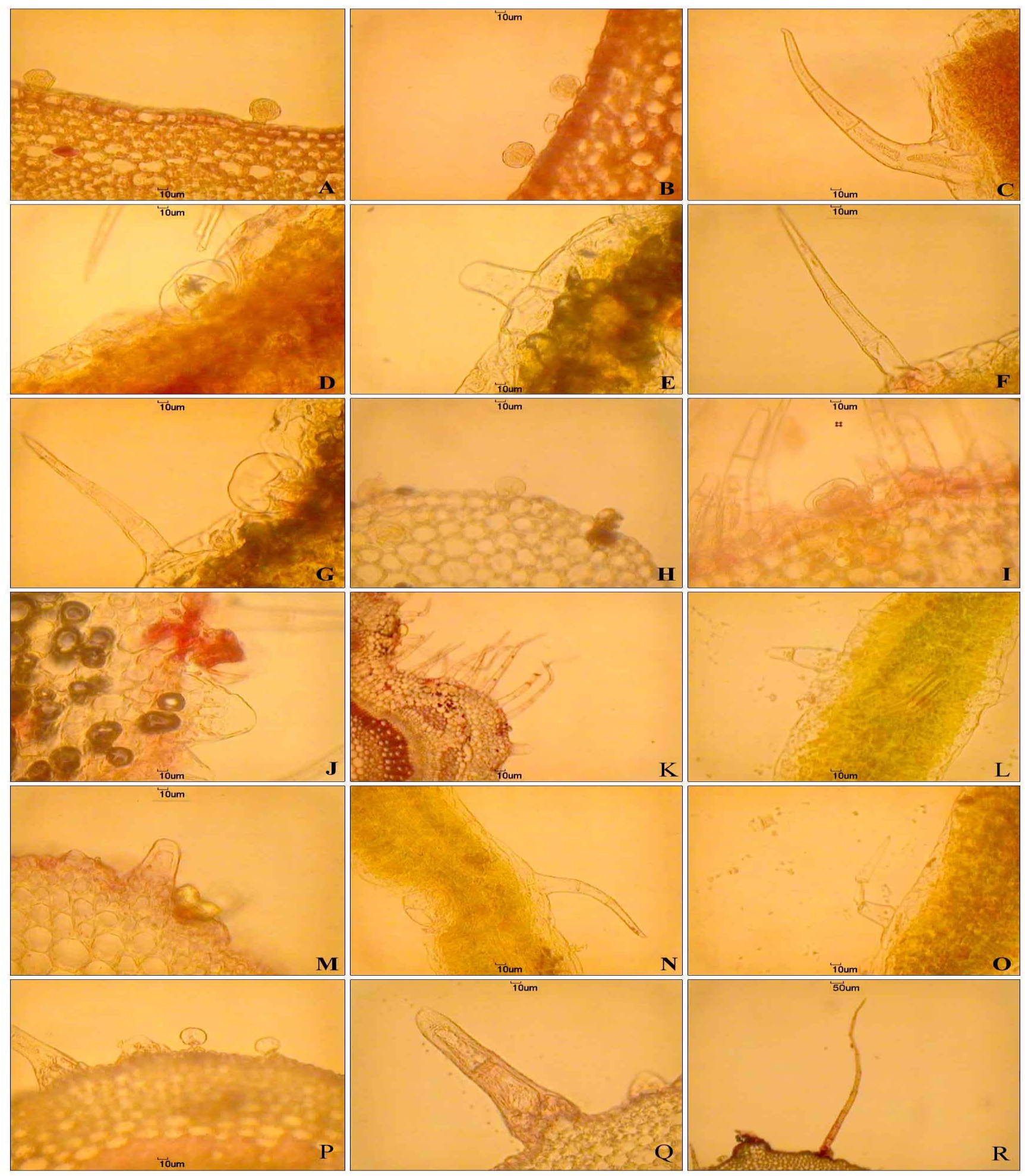

Fig. 1. Trichomes: A-C. O. gratissimum - Stem; D-G. O. kilimandscharicum - Leaf; H-K. O. kilimandscharicum - Stem; L-O. O. tenuiflorum Leaf; P-R. O. tenuiflorum - Stem.

(MT) in leaf trichomes are discussed in detail (43). The MTs are cysteine-rich, low-molecular-weight proteins that bind to heavy metals and play a role in plant metabolism and detoxification. It indicates the role of trichomes in detoxification of accumulated heavy metals and corresponding enhancement in plant metabolism.

\section{Key to the species}

1a. Stem trichomes only glandular type

1b. Stem trichomes both glandular and non-glandular types. 2a. Foliar glandular trichomes only capitate type .. O. gratissimum

2b. Foliar glandular trichomes only peltate type O. basilicum

3a. Stem or foliar trichomes having internodal thickening

3b. Stem or foliar trichomes lack internodal thickening ................................. O. americanum

4a. Foliar trichomes both capitate and peltate type .. O. kilimandscharicum

4b. Foliar trichomes only capitate type O. tenuiflorum 


\section{Conclusion}

Due to the presence of phytochemical compounds, Ocimum spp. are economically important. The glandular trichomes play significant role in the production of these compounds. In this aspect, the study on type and abundance of trichomes on leaf and stem of Ocimum spp. are very relevant. Eventhough they are collected from same environmental conditions, the selected species showed prominent micromorphological diversity. In the study, the species have unique trichome features in case of abundance, length and types that are very useful to identify the taxon at genus and species level. Both GTs and NGTs observed in all the species in which O. kilimandscharicum possessed abundant trichomes and $O$. basilicum was with less density of trichomes. GTs were peltate or capitate in nature in which the production of useful secondary metabolites were easily visible. The number of cells in head and stalk of GTs were varied in species and some of them possessed silica depositions. Septate or non-septate NGTs observed on leaves and stem, of which disrupted cells included in NGTs of $O$. americanum. The study promises the occurrence of phytochemical compounds in the head of GTs that may enlighten a new path to future studies.

\section{Acknowledgements}

The authors are thankful to the Principal, Korambayil Ahamed Haji Memorial Unity Women's College, Kerala, India for providing the laboratory facilities to complete the work systematically.

\section{Authors' contributions}

SE conceived, designed and performed the present work. DP critically analyzed the data and wrote the manuscript.

\section{Conflict of interests}

The authors have declared that no competing interests exist.

\section{References}

1. Gorenflot R. Biologie vegetale: plantes superieures; v. 1: Appareil vegetatif.-v. 2: Appareil reproducteur. 1980.

2. Erdtman G. Pollen morphology and plant taxonomy. Svensk Botanisk Tidskrift. 1945;38:163-68.

3. Cantino PD, Sanders RW. Subfamilial classification of Labiatae. $\begin{array}{ll}\text { Systematic } & \text { Botany. }\end{array}$ https://doi.org/10.2307/2418955

4. Ascensao L, Marques N, Pais MS. Glandular trichomes on vegetative and reproductive organs of Leonotis leonurus (Lamiaceae). Annals of Botany. 1995;75(6):619-26. https://doi.org/10.1006/anbo.1995.1067

5. Santos Tozin LRD, de Melo Silva SC, Rodrigues TM. Nonglandular trichomes in Lamiaceae and Verbenaceae species: morphological and histochemical features indicate more than physical protection. New Zealand Journal of Botany. 2016;54(4):446-57.

https://doi.org/10.1080/0028825X.2016.1205107
6. Dunkic V, Bezic N, Mileta T. Xeromorphism of trichomes in Lamiaceae species. Acta Botanica Croatica. 2001;60(2):277-83.

7. Celep F, Kahraman A, Atalay Z, Dogan M. Morphology, anatomy and trichome properties of' Lamium truncatum 'Boiss. (Lamiaceae) and their systematic implications. Australian Journal of Crop Science. 2011;5(2):147.

8. Jia P, Gao T, Xin H. Changes in structure and histochemistry of glandular trichomes of Thymus quinquecostatus Celak. The Scientific World Journal. 2012;3:187261. https://doi.org/10.1100/2012/187261

9. Kahraman A, Celep F, Dogan M. Anatomy, trichome morphology and palynology of Salvia chrysophylla Stapf (Lamiaceae). South African Journal of Botany. 2010;76(2):18795. https://doi.org/10.1016/j.sajb.2009.10.003

10. Manan AA, Taha RM, Mubarak EE, Elias $H$. In vitro flowering, glandular trichomes ultrastructure and essential oil accumulation in micropropagated Ocimum basilicum L. In vitro Cellular \& Developmental Biology-Plant. 2016;52(3):30314. https://doi.org/10.1007/s11627-016-9755-8

11. Santana ACMD, Pereira GS, Boaventura CM, Uetenabaro APT, Costa LCDB, Oliveira RAD. Rupture of glandular trichomes in Ocimum gratissimum leaves influences the content of essential oil during the drying method. Revista Brasileira de $\begin{array}{lrr}\text { Farmacognosia. } & \text { 2014;24(5): }\end{array}$ https://doi.org/10.1016/j.bjp.2014.10.006

12. Abdel KK. Morphological studies on trichomes of Brassicaceae in Egypt and taxonomic significance. Acta Botanica Croatica. 2005;64(1):57-73.

13. dos Santos Tozin LR, Rodrigues TM. Glandular trichomes in the tree-basil (Ocimum gratissimum L., Lamiaceae): Morphological features with emphasis on the cytoskeleton. Flora. 2019;259:151459. https://doi.org/10.1016/j.flora.2019.151459

14. Gang DR, Simon J, Lewinsohn E, Pichersky E. Peltate glandular trichomes of Ocimum basilicum L. (Sweet Basil) contain high levels of enzymes involved in the biosynthesis of phenylpropenes. Journal of Herbs, Spices and Medicinal Plants.

https://doi.org/10.1300/J044v09n02_27

2002;9(2-3):189-95

15. Karabourniotis G, Liakopoulos G, Nikolopoulos D, Bresta P. Protective and defensive roles of non-glandular trichomes against multiple stresses: Structure-function coordination. Journal of Forestry Research. 2020;31(1):1-12. https://doi.org/10.1007/s11676-019-01034-4

16. Kelsey RG, Shafizadeh F. Glandular trichomes and sesquiterpene lactones of Artemisia nova (Asteraceae). Biochemical Systematics and Ecology. 1980;8(4):371-77. https:// doi.org/10.1016/0305-1978(80)90039-3

17. Paton A, Harley RM, Harley MM. Ocimum: an overview of classification and relationships. In Basil CRC Press. 1999;11-46.

18. Simon JE, Quinn J, Murray RG. Basil: a source of essential oils. Advances in New Crops. 1990; 484-89.

19. Pushpangadan P, Bradu BL. Basil. In: Chadha KL, Gupta R (eds.) Advances in Horticulture, Medicinal and Aromatic Plants, Malhotra Pub House, New Delhi, India. 1995;11:628-57.

20. Sakalauskaite J, Viskelis P, Duchovskis P, Dambrauskiene E, Sakalauskiene S, Samuoliene G, Brazaityte A. Supplementary UV-B irradiation effects on basil (Ocimum basilicum L.) growth and phytochemical properties. Journal of Food, Agriculture and Environment. 2012;10(3\&4):342-46.

21. Joshi B, Sah GP, Basnet BB, Bhatt MR, Sharma D, Subedi K, Malla R. Phytochemical extraction and antimicrobial properties of different medicinal plants: Ocimum sanctum (Tulsi), Eugenia caryophyllata (Clove), Achyranthes bidentata (Datiwan) and Azadirachta indica (Neem). Journal of Microbiology and Antimicrobials. 2011;3(1):1-7.

22. An L, Zhou Z, Yan A, Gan Y. Progress on trichome development regulated by phytohormone signaling. Plant Signaling and Behavior. https://doi.org/10.4161/psb.6.12.18120 2011;6(12):1959-1962

23. AbdulRahaman AA, Oladele FA. Stomata, trichomes and epidermal cells as diagnostic features in six species of the genus Ocimum L. (Lamiaceae). Nigerian Journal of Botany. 2005;18:214-23. 
24. Goncalves LDA, Azevedo AA, Otoni WC. Characterization and ontogeny of the glandular trichomes of Ocimum selloi Benth. (Lamiaceae). Acta Botanica Brasilica. 2010;24(4): 909-15. https://doi.org/10.1590/S0102-33062010000400005

25. Morohashi K, Zhao M, Yang M, Read B, Lloyd A, Lamb R, Grotewold E. Participation of the Arabidopsis bHLH factor GL3 in trichome initiation regulatory events. Plant Physiology. 2007;145(3):736-46. https://doi.org/10.1104/pp.107.104521

26. McLellan T. Correlated evolution of leaf shape and trichomes in Begonia dregei (Begoniaceae). American Journal of Botany. 2005;92(10):1616-23. https://doi.org/10.3732/ajb.92.10.1616

27. Naidoo Y, Kasim N, Heneidak S, Nicholas A, Naidoo G. Foliar secretory trichomes of Ocimum obovatum (Lamiaceae) micromorphological structure and histochemistry. Plant Systematics and Evolution. 2013;299(5):873-85. https://doi.org/10.1007/s00606-013-0770-5

28. Chandra M, Kushwaha S, Sangwan NS. Comparative transcriptome analysis to identify putative genes related to trichome development in Ocimum species. Molecular Biology Reports. 2020;1-12. https://doi.org/10.1007/s11033-020-05710-1

29. Gul S, Ahmad M, Zafar M, Bahadur S, Sultana S, Ashfaq S, Siddiq Z. Foliar epidermal anatomy of Lamiaceae with special emphasis on their trichomes diversity using scanning electron microscopy. Microscopy Research and Technique. 2019;82(3):206-23. https://doi.org/10.1002/jemt.23157

30. Yerger EH, Grazzini RA, Hesk D, Cox-Foster DL, Craig R, Mumma RO. A rapid method for isolating glandular trichomes. Plant Physiology. 1992;99(1):1-7. https://doi.org/10.1104/pp.99.1.1

31. Gairola S, Naidoo Y, Bhatt A, Nicholas A. An investigation of the foliar trichomes of Tetradenia riparia (Hochst.) Codd (Lamiaceae): An important medicinal plant of Southern Africa. Flora. https://doi.org/10.1016/j.flora.2008.04.002 2009;204(4):325-30

32. Costa LC, Pinto JE, Castro EM, Alves E, Rosal LF, Bertolucci SK Evangelino TS. Yield and composition of the essential oil of Ocimum selloi Benth. cultivated under colored netting. Journal of Essential Oil Research. 2010;22(1):34-39. https://doi.org/10.1080/10412905.2010.9700260

33. Martins ER, Casali VWD, Barbosa LCA, Carazza F. Essential oil in the taxonomy of Ocimum selloi Benth. Journal of the Brazilian Chemical Society. 1996;8:29-32. https://doi.org/10.1590/S0103-50531997000100006

34. Benning C, Xu C, Awai K. Non-vesicular and vesicular lipid trafficking involving plastids. Current Opinion in Plant Biology. https://doi.org/10.1016/j.pbi.2006.03.012 2006;9(3),241-47

35. Weryszko-Chmielewska E, Chernetskyy M. Structure of trichomes from the surface of leaves of some species of Kalanchoe Adans. Acta Biologica Cracoviensia Series Botanica. 2005;47(2):15-22.

36. Svidenko L, Grygorieva O, Vergun O, Hudz N, Sedlackova VH, Simkova J, Brindza J. Characteristic of leaf peltate glandular trichomes and their variability of some Lamiaceae martinov family species. Agrobiodiversity for Improving Nutrition, Health and Life 2018 . https://doi.org/10.15414/agrobiodiversity.2018.2585-8246.124132

37. Ascensao L, Mota L, Castro MD. Glandular trichomes on the leaves and flowers of Plectranthus ornatus: B C D A 749 morphology, distribution and histochemistry. Annals of Botany. 1999;84:437-47. https://doi.org/10.1006/anbo.1999.0937

38. Abe J. Silicon deposition in leaf trichomes of Cucurbitaceae horticultural plants: A short report. American Journal of Plant Sciences. https://doi.org/10.4236/ajps.2019.103034

2019;10(3):486-90.

39. Katz O, Lev-Yadun S, Bar P. Plasticity and variability in the patterns of phytolith formation in Asteraceae species along a large rainfall gradient in Israel. Flora. 2013; 208(7):438-44. https://doi.org/10.1016/j.flora.2013.07.005

40. Motomura H, Fujii T, Suzuki M. Silica deposition in abaxial epidermis before the opening of leaf blades of Pleioblastus chino (Poaceae, Bambusoideae). Annals of Botany. 2006;97(4) 513-19. https://doi.org/10.1093/aob/mcl014

41. Tozin LRDS, Rodrigues TM. Morphology and histochemistry of glandular trichomes in Hyptis villosa Pohl ex Benth. (Lamiaceae) and differential labeling of cytoskeletal elements. Acta Botanica Brasilica. 2017;31(3):330-43. https://doi.org/10.1590/0102-33062016abb0292

42. Farago PV, de Paula JP, Bittencourt JIM, Zarpellon V, Checchia LEM. Atividade antibacteriana de oleos essenciais de Ocimum selloi Benth. (Lamiaceae). Publicatio UEPG: Ciencias Biological Saude. https://doi.org/10.5212/Publ.Biologicas.v.10i3.0007

43. Foley RC, Singh KB. Isolation of a Vicia faba metallothioneinlike gene: expression in foliar trichomes. Plant Molecular Biology. 1994;26(1):435-44. https://doi.org/10.1007/BF00039552

\section{Additional information}

Peer review information: Plant Science Today thanks Sectional Editor and the other anonymous reviewers for their contribution to the peer review of this work.

Reprints and permissions information is available at https://horizonepublishing.com/journals/index.php/PST/open_access_policy

Publisher's Note: Horizon e-Publishing Group remains neutral with regard to jurisdictional claims in published maps and institutional affiliations.

To cite this article: Sanoj E, Deepa P. Micromorphological variations of trichomes in the genus Ocimum L.. Plant Science Today. 2021;8(3):429-436. https://doi.org/10.14719/pst.2021.8.3.1006

Plant Science Today, published by Horizon e-Publishing Group, is covered by Scopus, Web of Science, BIOSIS Previews, Clarivate Analytics, etc. See https://horizonepublishing.com/journals/index.php/PST/indexing_abstracting 